UDC 81'373.43:316.472.4:339.16:004.738.5

DOI https://doi.org/10.32838/2710-4656/2021.1-2/09

Haydanka D. $V$.

Uzhhorod National University

\title{
PRAGMATIC ROLE OF CREATIVE AD-HOC UNITS IN SOCIAL MEDIA CONTENT MAKING
}

The present article elucidates the role of lexical creativity in creating content for social networks. Recently influencers promote both their online personas and certain products through microblogging. Hence, the article highlights the tactics of self-branding being the key communicative strategy behind each creative ad-hoc coinage on Pinterest, Instagram and Twitter. Firstly, the author gives an insight into the social media functioning and its pervasiveness around the globe. Further on, the author proposes her own classification of functions of ad-hoc units in microblogging. Based on the scientific literature analysis, we can argue that the functions of the occasional words are likely to fall into common (nominative, textual-stylistic/creative, expressive-evaluative and text-forming), and metacommunicative, predetermined by a number of extralinguistic factors. The study findings prove that influencers and bloggers make use of lexical creativity to attract attention to their posts, to humorously reinterpret the events of extralinguistic reality, and promote a product they are explicitly or implicitly advertising. Through the prism of pragmatics, ad-hoc units on social networks function to promote and sell a product and are often employed by social media managers. Another reason is the desire for self-branding and creation of the so-called commodified persona that helps social media influencers self-express and attract new followers and subscribers. From the pragmatic perspective, ad-hoc units in social networks predominantly serve as markers of the strategy of self-branding, realised by the communicative tactic of evoking associations, communicative tactic of appealing to emotions, the tactic of epatage, and the tactic of bonding in order to reframe the situation. Hence, the importance of social networks, particularly Twitter, Pininterest and Instagram is growing not only for entertaining purposes, but for social media marketing (self-presentation and branding), due to which influencers and social media managers use various linguistic means to attract attention either to themselves, or to the product they are promoting.

Key words: ad-hoc unit, social network, microblogging, commodified persona, communicative strategy of self-branding.

Introduction. Social networking services lay a prolific ground for ad-hoc word-formation, since unusual coinages attract attention, hence becoming Internet memes and helping their authors and creators develop a likeable, memorable and distinct content creating style. Hence, in such a manner, users are learning to live within possibilities and constraints, posed by mediated communication. As far as social networks occupy an important part of a modern youngster's life, it is expedient to consider why influencers in social networks take advantage of ad-hoc words. Moreover, ad-hoc words are used not only for humorous purposes or with an intention to spice up a short caption on social media. Frequently, there are deeper motives to employ unusual lexical units, mainly to manipulate the outlook and desires of the social media target audience either to attract attention to personas, or to compel followers to like and further buy certain commodities. Therefore, our research interest is stipulated by the fact that it addresses the $21^{\text {st }}$-century English social interaction in online marketing and describes the most recent research into ad-hoc derivation.

Analysis of latest publications. Social media feeds pose a productive field of multidisciplinary research interest, ranging from applied linguistics, computer studies and psychology up to image-making and marketing. Beyond doubt, scholars have attempted to understand various aspects of social networking, such as types and properties of social networks, peculiarities of social communication, ways of creating a marketable social media image, emotional intelligence of followers, the content of the social media discourse and the way it is presented. Social media influencers frequently reach the status of a celebrity leading to users often adopting manners, practices, mindsets and the type of online behaviour of such "commodified personas", as M.Zappavigna puts it [7]. Scholars often focus on structural and semantic aspects of occasional derivation, leaving the functional-communicative aspect unaddressed, but the very structure of the occasional unit directly affects the stylistic coloring of the text. In a broad 
sense, occasional derivation performs nominative and communicative functions, respectively to its functional purpose. Hence, our research interest lies in determining communicative tactics within certain communicative strategies that underlie each ad-hoc unit creation.

Problem statement. Social networking services, or microblogging (Boyd, Papacharissi, Zappavigna), have a tremendous impact upon society life, "constructing "public" with "a common understanding of the world, a shared identity, a claim to inclusiveness, a consensus regarding the collective interest" [6, p. 9]. Since the time of their emergence in early 2000 s, social media gave rise to a distinct type of online speech that could both attract unmediated audiences and influence their opinions. A rapid development of networking technologies have resulted in the following: 1) the loss of privacy; 2) pervasiveness since they operate as platforms both for influencing and online marketing; 3) authentic content and distinct social media style [4, p. 49-54].

People have used Twitter, Instagram and Pininterest to enact relationships with their readers rather than either narrate the significant events, or document minutiae of their lives. In this light, social networking services function as "the stream of online conversation occurring across semiotic modes (e.g. blogs, online chats, networking sites and online marketing platforms), with Twitter operating as realtime discourse and an effective way to gather useful information, and microblogging helping find out about dominant trends in society life $[7$, p. 6]. As D. Boyd [4, p. 39)] suggests, the main peculiarities of social networks are the following: profile creation, generation of large numbers of affiliated users, commonly known as 'friends' (e.g. Facebook friends) or 'followers' (e.g. Twitter followers). Boyd defines social media as a genre of 'networked publics' with the 'imagined collective', characterised by: 1) persistence (capture and archiving of content); 2) replicability (duplication of content); 3) scalability (broad visibility of content); 4) searchability (access to content via search) [4].

From the semiotic and linguistic points of view, the social media possess the following peculiarities: 1) ambient affiliation - the use of hashtags to mark the topic of captions, with people sharing associated values bonding around these self-defined topics; 2) social media memes - word template memes used for affiliation; 3) social media slang to invoke solidarity; 4) social media humour; 5) evaluative language related to politics (e.g. tweets or hashtags containing the famous politicians' names) [7, p. 14].
Findings and Discussion. According to the newest trends in ad-hoc derivation analysis ad-hoc words are classified in terms of their structural characteristics and cognitive nature to demonstrate the ties between the word-formation types and pieces of knowledge they represent. Hence, they are divided into ad-hoc units that convey aggregated knowledge (represented by compounding and affixation), ad-hoc units that convey condensed knowledge (represented by blends, acronyms, and different types of abbreviations), and ad-hoc words that convey modified knowledge (represented by conversion, onomatopoea and semantic derivation, based on metaphoric and metonymic transposition) [1].

As the findings of our study indicate, ad-hoc units in social networks are used for two main purposes:

1) to attract attention or for humorous effect, used by social media influencers and celebrities: felfie - an evolution of the selfie, a photo you take of you and your family (family + selfie); troll: (verb) make a deliberately offensive or provocative online posting with the aim of upsetting someone or eliciting an angry response from them, Twinterview (twitter + interview): Ever sat glued to Twitter as your favourite sports star, singer or author gets grilled by their followers? Well then, you've watched a twinterview; askhole - a person, asking numerous irrelevant question on Instagram $[8 ; 10]$; such ironic ad-hoc coinages often contribute to creating a relatable and likeable image of an account-holder or blogger;

2) to promote a product, used by social media managers that developed their own social marketing terms (Listicle - a list-based article). This type of content is often popular on social media because of its quick, easy-to-digest format [8]. Such coinages often serve as terms on various IT and e-marketing platforms and frequently become lexicalised neologisms.

The ad-hoc units of the first group are used in the Instagram accounts of famous people for the following reasons:

1) to expand their readership and become closer to their followers by inventing funny and likeable words that are easy to interpret. Most of these ad-hoc words are used to give a humorous and witty touch: dudevorce (dude + divorce) - when two bosom male friends stop being friends; nexterday (next + yesterday) - today; chiptease - buying a bag of potato chips thinking it is full, but finding it is just air; masturwait (masturbate + wait) - being ready to masturbate but have a video to buffer; belfie (bottom + selfie) - a selfie where one's backside is the main focus of artistic attention; dejabrew (dejavu + brew) - slowly remember things 
one did while being drunk; significunt (significant + cunt) - a stupid gossip-loving woman who thinks she is very important $[8,13]$;

2) to share their feelings (mainly negative) and evoke empathy, sometimes sympathy. The majority of occasional words of this group are intellectual and thought-provoking and not very easy to interpret for a mass audience. Mostly they appear in blogs of psychologists, thought leaders and motivational speakers: onliness (only + loneliness) - maintaining a constant online presence in order to instantly react to different Internet developments, no matter how insignificant; torrschlusspanic (borrowed from German, literally "gate shut panic") - fear that time is running out to achieve life goals; errorist (terrorist + error) - someone who constantly makes mistakes or is always wrong. These ad-hoc units often provide names for new abstract concepts or phenomena that are related to the inner world of a person $[8 ; 13]$;

3) acronyms and abbreviations to write concise text messages or express emotions by using onomatopoeic verbal substitutes for interjections: eglaf - a word that has no meaning but can be used to replace any other word; yoisho - a word without meaning that imitates a sound of flopping into a chair. Also, abbreviated ad-hoc units often refer to types of photo and video content (foodporn, legfie, petfie), methods of their creation (Instapan); people and pets involved in creating photo content (beautygrammer, yogagrammer kidfluencer, instadog, petfluencer), and photo and video retouch and promotion applications (instahamster, leogram) [2, p. 195];

2) ad-hoc words used by social media marketing experts to promote various products, through social networking tools for running, analysing social ads, and creating high-performing social media content and ad campaigns for ad targeting, budgeting, and optimization: Brand advocate - a customer who leaves positive reviews, e. g. "For tips promoting brand advocacy, read "How to Turn Customers Into Brand Advocates"; CTR (Clickthrough rate) the percentage of people that see your post and click on it: "On Facebook, CTR is equal to (link clicks / post impressions) $x 100 \%$. For more details on social media ad metrics like CTR, CVR and CPC, check out Facebook Ad Costs Explained"; Cross-channelgoing across all different social networks of a person, e.g. "A cross-channel social strategy" is a strategy that aligns your objectives across all the social networks your brand is present on"; memejacking trying to find the latest memes (funny pieces of text, videos, or viral images) to connect with younger audiences, e.g. If brands are self-aware enough and have a healthy sense of irony, though, they can pull off memejacking "[8]. Active presence on social media can boost online sales since online platforms are highly competitive. So social media marketing managers employ various techniques to attract potential customers, linguistically creative units being one of those. Hence, e-commerce presents one of highly productive areas for ad-hoc word-formation.

Social networks posts are often restricted by a limited number of characters, for this reason, the person, making a post has to be brief, but catchy to gather as many likes as possible. Thus, we can see that ad-hoc words that convey condensed knowledge, represented by blends, abbreviations and acronyms make up the most numerous group of ad-hoc words, used on social media: cellfish - an individual, continuing to talk on their phone so as to be rude or inconsiderate of other people [13]), destinasea - when you get where you were intending to go, but forget why you wanted to go there in the first place [13].

Modified ad-hoc units rank the second in the corpus under consideration, the prevalent wordformation types being conversion and analogy. Conversion is represented by primary (adjectivation, noun verbalization): to bangover, $\mathrm{v}$ (from bangover, n) - to wake up with sore neck and head as a result of excessive headbanging the previous night; to jayus, $\mathrm{v}$ - to joke poorly but nevertheless cause laughter (from noun jayus); to chatbot (from chatbot, n) - to use artificial intelligence to answer questions and perform simple tasks in messaging apps such as Facebook Messenger for customer service, data and lead collection, shopping recommendations, and more [13].

From the pragmatic perspective, ad-hoc units in social networks predominantly serve as markers of the communicative strategy of self-branding.

The communicative strategy of self-branding is based on self-promotion and involves demonstration of one's own competence, skills, experience, or differences from others in order to meet the expectations of the followers or compliance with the chosen social role [3, p. 130]: All you have to do is go to katyperrycollections! I see you and I love you $\checkmark$ จ

Most ad-hoc words on social networks function as colourful epithets, metaphors to make somebody's best features pop. Self-branding is expressed in a set of axiologically-oriented topics [1], among which the following are dominant: 1) family and religious values; I'm MAMACITAAAAAA [10]; 2) providing personal information: I'm Lil sporty-cutie, bored in the house and housebored [11]; 3) reminders 
of one's own status, reputation, popularity: Tap for details! kyliecosmetics [10]; 4) presentation of one's own achievements: Kylie - Illuminaticonfirmed; Kylieskin is officially available in Europe [10]; 5) description of themselves: Now post-quarantine I'm a quarantine-bae [10].

Stylistic figures that realize the communicative tactic of self-branding are figures of quality, in particular epithets, and ascending gradation, mostly verbalized by blends (It will be overmorrow - the day after tomorrow), compounds (Yogapants are pushup bra for butt, making you look like you have an ass), and affixal derivatives (a post-quarantine bae), abbreviations (YOLO - You only live once: carpe diem for stupid people) [12], and semantic derivation (Bitch is any girl prettier than me), or daffinitions (I'm a catholic, because I love cats) [13].

The use of blends and daffinitions reflects the ironic self-perception of influencers, based on the principle of saving mental and speech effort (Recently I've been suffering from napstipation - the desire to have a nap that cannot be fulfilled. Flirtationship is more than flirt, but less than relationship) [11].

The communicative tactic of evoking associations, whose success depends on how the receiver understands the message and responds to the communicative intention of the author. By employing certain associative links, verbalized by ad-hoc units, formed by analogy, the author plays a word game with their readers: This guy is transfinancial (a rich man living in a poor man's body. A real financial identity disorder) [10]. The main stylistic figure to realize this communicative tactic is allusion-based jokes at film titles, film and literary characters, restaurant chains as precedents: Depressothat is the feeling I get when I run out of coffee [10]. The main language means of this tactic realisation are daffinitions, blends and affixal derivatives: We are obviously having a nonversation - a pointless conversation about nothing $[12 ; 13]$.

The communicative tactic of appealing to emotions is based on empathy and is supposed to evoke a certain emotional response. At the stylistic level, it is realized by hyperbolic comparisons, which emphasize the obvious exaggeration and expressiveness of the statement, epithets and metaphors, verbalized by different types of ad-hoc units: I feel like a doppelbanger (a person that has sexual intercourse with someone that looks identical to them but not related) [13].

The communicative tactic of epatage allows influencers to reveal shocking details of their intimate lives nd other taboo topics, deliberately emphasizing exaggerated sexuality: I'm a badgal RIRI [11]. To bisexual is to be able to reach someone's pants and be satisfied with whatever you find there [13]. The manipulative dimension of this communicative tactic reflects quite an opposite effect on the audience: scandalous behaviour and unconventional views on relationships provoke a mixed reaction of the audience, Consequently, an influencer shapes the image of a charismatic commodified persona, who goes against the generally accepted standards, with their whims bringing aesthetic pleasure to followers.

The communicative tactic of bonding with the audience is mainly used to unite virtual interlocutors and through humour, based on intragroup connections. Bonding $[5$, p. 121]) involves establishing contacts between the accountholder and the audience with the help of expressive occasional units, aimed to make fun of the situation without harming anybody's feelings (Here I am in my last glampt prequarentina. Gather your shoefriends around and tune in! [9] Humorous teasing at a stylistic level is realized by litotes, verbalised by suffixal derivatives with a diminutive suffix -ie- (KatyPursey), the use of quotations and allusions, but mostly through irony (Have you HERD? It's the best night of the year, C'mon girls, gather for a Disneynight) [11], which is implicit because the reader cannot always explain the intended meaning of the message, which appeals to background knowledge: Katie! Ur amazing! POSHNICEY! (allusion to Victoria Beckham's Spice Girls nickname). The irony is verbalized by daffinitions: (SKATY PERRY!) [9], compounds (In these trying times, I am so thankful for my precious little puppy missnuggetperry), suffixal derivatives (Sissy's gone trippy! Check her out and your new Springy staples) [9]. In the conditions of the Covid19 pandemic, bloggers frequently resort to this tactic to reframe a seemingly negative situation, or give it a more positive humorous touch. In such a way, on Pininterst and Instagram there appeared numerous ad-hoc units, mostly blends, containing the component Covid, e.g.: We were so scared to go out that we became real covidiots. Ten years from now we may as well expect the rise of quaranteens $[12 ; 13]$. A number of covidivorces is constantly increasing [12]. Such humorous items hardly appear in academic sources or medical articles, rather being a jocular way to get through self-isolation and loneliness, caused by the pandemic, connect with the audience and find their emotional feedback.

So, the communicative tactic of bonding is based on self-irony, humorous attitude towards somehow negative situations and is used to establish 
and maintain friendly virtual relationships between the author and their followers.

Conclusions. Scholars often focus on structural and semantic aspects of occasional derivation, leaving the functional-communicative aspect unaddressed, but the very structure of the ad-hoc unit directly affects the stylistic colouring of the text. However, in many cases, the creation of ad-hoc units helps the authors express themselves, so the focus is exactly the emotional-expressive value of the ad-hoc units.

According to the newest trends in ad-hoc derivation analysis ad-hoc words aggregated knowledge, condensed knowledge, and modified knowledge. The main functions are pragmatic or communicative: to establish closer ties with followers, share feelings, and communicating with the target audience.

The two key pragmatic functions of ad-hoc words in social networks, are the following: to attract attention to one's personality via a personal account and create humorous effect, which accounts for selfbranding function. Ad-hoc units of this type are mostly used by famous bloggers, influencers and celebrities and mainly these are creative blends, acronyms and words, coined by analogy. Secondly, Instagram, Facebook and Twitter exist as platforms to promote products and for advertising purposes and constitute Instagram marketing terms, mostly represented by compounding and abbreviations.

Since the main purpose of influencers on social networking services is to create a commodified persona to expand the number of followers the prevailing communicative tactic is the communicative strategy of self-branding, realised by The communicative tactic of evoking associations and communicative tactic of appealing to emotions, along with the tactic of epatage proved less dominant, rather attending the key self-branding tactic. The tactic of bonding in order to reframe the situation is yet another tactic that proved rather high frequency in the illustrative material. Its main purpose in the discourse of social media is to humorously reinterpret the situation that seemed negative.

\section{References:}

1. Гайданка Д. Оказіональне словотворення у сучасному англомовному кінодискурсі: лінгвокогнітивний і комунікативно-когнітивний аспекти [Текст] : автореф. дис. ... канд. філол. наук : 10.02.04. Херсон. держ. ун-т. Херсон, 2018. 20 с.

2. Сеньків О., Петриця Л. Лінгвокреативний потенціал соціальних мереж (на прикладі соцмережі інстаграм). Молодий вчений. 2019. № 4.2 (68.2). С. 194-196.

3. Сорокина Ю.В. Убеждающие и защитные тактики коммуникативной стратегии самопрезентации в лекционном дискурсе. Вестник Челябинского государственного университета. Серия: Филология, Исскуствоведение. 2014. № 91. С. 128-131.

4. Boyd D.M. Social Network Sites as Networked Publics: Affordances, Dynamics, and Implications. Networked Self: Identity, Community, and Culture on Social Network Sites, ed. By Zizi Papacharissi. New York: Routledge, 2010, P. 39-58.

5. Bousfield D., McIntyre D. Emotion and empathy in Martin Scorcese's «Goodfellas»: A case study of the «funny guy» scene. Telecinematic Discourse: Approaches to the Language of Films and Television Series. Ed. by R. Piazza, M. Bednarek, F. Rossi. Amsterdam : John Benjamins, 2011. P. 105-125.

6. Livingstone S. Audiences and Publics: When Cultural Engagement Matters for the Public Sphere. Portland, OR: Intellect, 2005. $250 \mathrm{p}$.

7. Zappavigna M. Discourse of Twitter and Social Media. How We Use Language to Create Affiliation on the Web. Discourse Continuum Series. New York: Continuum, 2012. 240 p.

8. Falcon.io. URL : https://www.falcon.io/insights-hub/topics/social-media-management/social-media-termsbuzzwords-definitions-marketers-need-to-know/ (Accessed: 10.02.2021)

9. Instagram - katyperry. URL : https://www.instagram.com/katyperry/ (Accessed: 10.02.2021).

10. Instagram - kyliejenner. URL : https://www.instagram.com/kyliejenner/ (Accessed: 10.02.2021).

11. Instagram - rihanna. URL : https://www.instagram.com/rihanna/ (Accessed: 10.02.2021).

12. Macmillan dictionary blog. URL : http://www.macmillandictionaryblog.com/new-words-from-socialmedia (Accessed: 10.02.2021).

13. Pinterest. URL : https://www.pinterest.com/pin/417779302911513161/?d=t\&mt=signup (Accessed: 10.02.2021).

\section{ГайДаНКа Д. В. ПРАГМАТИЧНА РОЛЬ КРЕАТИВНИХ ОКАЗІОНАЛІЗМІВ ПІД ЧАС СТВОРЕННЯ КОНТЕНТУ ДЛЯ СОЦМЕРЕЖ}

У статті висвітлюється роль лінгвокреативності під час створення контенту для соиіальних мережс. Інфлюенсери у соимережах через власні акаунти як рекламують власну особистість в Інтернеті, так 
і просувають товари на замовлення за допомогою мікроблогінгу. Отже, розкривається комунікативна стратегія самореклами, або селф-брендингу, яка є ключовою комунікативною стратегією блогів y Pininterest, Instagram ma Twitter. Насамперед, особлива увага приділяється функціонування соиіальних медіа. Далі авторка пропонує власну класифікацію функцій мікроблогінгу. На основі проаналізованої наукової літератури постулюється, що функиії оказіональних слів поділяються на загальні (номінативні, текстово-стилістичні / творчі, експресивно-оцінні та текстотворчі) та метакомунікативні, зумовлені низкою екстралінгвістичних факторів . Крізь призму прагматики оказіоналізми в сочіальних мережах відіграють значну роль для просування та продажу товару, часто застосовуючись у соимережевому маркетингу. Ще однією причиною засилля креативних новотворів в соимережах є прагнення блогерів до самореклами та створення так званої «оварної особистості», яка допомагає інфлюенсерам самовиражатися та залучати нових підписників, розширювати власну читацьку авдиторію у соиіальних мережах. За результатами дослідження можемо стверджувати, що інтернет-інфлюенсери та блогери послуговуються лінгвокреативністю зметою привернення уваги до власних постів, комічного переосмислення екстралінгвальної реальності зметою реперспективізації предметної ситуації та явного чи прихованого рекламування продукту, який вони згадують у власних публікаціях. Із прагматичної точки зору оказіоналізми в соціальних мережсах переважно слугують маркерами стратегії селф-брендингу, щуо реалізується комунікативною тактикою зверення до асоціацій, комунікативного впливу на емоції, тактикою епатажу та тактикою бондингу. Відтак значення соиіальних мереж, зокрема Twitter, Pininterest ma Instagram, зростає не лише завдяки розважальному та візуально привабливому контенту, але й з метою маркетингу в соиіальних мережсах (самопрезентація та брендинг). Як наслідок, менеджери у соиіальних мережсах застосовують різноманітні лінгвальні засоби для привернення уваги до власної особистості та реклами продуктів на замовлення.

Ключові слова: оказіоналізм, сочіальна мережа, мікроблогінг, товарна особистість, комунікативна стратегія селф-брендингу. 